\title{
Development of Teacher Guidebook for Photoelectric Effects Instructional Using Predict-Observe-Explain Strategy with PhET Interactive Simulation
}

\author{
Siswoyo \\ Prodi Pendidikan Fisika, Fakultas MIPA, Universitas Negeri Jakarta \\ Jalan Rawamangun Muka 13320 \\ 凹: siswoyo@unj.ac.id
}

\begin{abstract}
This study developed a teacher book guide for photoelectric effects instructional using the Predict Observe Explain strategy with PhET interactive simulation. This study used the ADDIE Model consisting of Analysis, Design, Develop, Implementation and Evaluation. The results of the validation component of the graphics feasibility were 91.1 (very feasible), the validation of the content feasibility component was 97.5 (very feasible), and the validation of the instructional feasibility component was 81.7 (very feasible). While the test component of instructional feasibility by the teacher obtained results of 85.9 (very feasible). The results concluded that the teacher book guide for photoelectric effects instructional using the Predict Observe Explain strategy with PhET interactive simulation was declared very feasible to be used as a teacher guidebook.
\end{abstract}

Keywords: teacher guidebook, PhET, POE, photoelectric effect

\section{INTRODUCTION}

Teacher's profession is a specialized field of work carried out based on the following principles: 1) having talent, interest, soul calling, and idealism; 2) have a commitment to improving the quality of education, faith, piety, and noble character; 3) have academic qualifications and educational background in accordance with the field of duty; 4) have the competencies needed in accordance with the field of duty; 5) have responsibility for carrying out professional duties; 6) obtain income determined according to work performance; 7) have the opportunity to develop professionalism on an ongoing basis with lifelong learning; 8 ) have guaranteed legal protection in carrying out professional duties; 9) and has a professional organization that has the authority to regulate matters relating to teacher professionalism. A professional teacher must fulfill the four teacher competencies set out in the Republic of Indonesia Law in Number 14 of 2005 concerning Teachers and Lecturers, namely: (1) Pedagogical competencies, (2) Personality competencies, (3) Professional competencies, and (4) Competence social.

There are many efforts made by the government and other educational institutions to achieve this professionalism such as seminars, training, and workshops on the implementation of the applicable curriculum. By carrying out training in the preparation of psychomotor domain assessment instruments can improve teacher skills in selecting and compiling skills assessment instruments with observations and tests. Skills in compiling guidelines for scoring trainees for high school / Madrasah Aliyah Physics teachers can increase (Istiyono et al. 2017). Likewise with the workshop activities to improve the ability to design laboratory activities that are oriented towards the scientific approach the teachers obtain good 
grades (Admoko et al. 2015). In applying the curriculum in schools that are pilot projects, it is concluded that the physics teacher's understanding of Curriculum 2013 is in a very good category. Planning for physics teachers in the State Madrasah Aliyahpilot project is in a good category. The implementation of learning by physics teachers in the MAN pilot project is in a good category. The physics teacher's assessment in the State Madrasah Aliyah pilot project is in a good category (Fadilah et al. 2016).

The results of the research by Kaleka, MU (2014) show the ability of high school / Madrasah Aliyah physics teachers in compiling learning outcomes assessment instruments included in the high criteria. Seen from each variable obtained: (1) The ability of high school / Madrasah Aliyah physics teachers in compiling the end-of-semester test questions grid is included in the high criteria; (2) The ability of high school / Madrasah Aliyah physics teachers in preparing test questions at the end of the semester is included in the criteria of very high; (3) The ability of high school / Madrasah Aliyahphysics teachers in processing end-of-semester test results (changing scores to grades) is included in the high criteria.

Similarly, the results of the research of Wulandari \& Mundilarto (2016) shows that the pedagogical competencies of physics teachers in implementing the scientific approach as a whole are categorized as good Professional competencies in physics teachers in implementing the overall scientific approach are also categorized as good. Correlation coefficients between principals' leadership and professional competence in implementing the physics teacher's scientific approach are categorized as having strong correlations. However, the correlation coefficient between principals' leadership and pedagogical competencies in implementing the scientific approach of physics teachers is categorized as having a very weak correlation. The results of the study also found that there was no significant correlation between the training followed by the teacher and the pedagogical competence of the physics teacher in implementing the scientific approach. There is no significant correlation between the training followed by the teacher and the professional competence of the physics teacher in implementing the scientific approach of the physics teacher.

Based on the results of Putri, RF, \& Jumadi, J (2017) regarding the ability of Public High School Physics teachers in implementing learning models determined in the 2013 Curriculum and the constraints faced can be concluded (1) the ability of deep Public High School Physics teachers planning to learn with learning models determined in 2013 Curriculum is in a good category; (2) the ability of Public High School Physics teachers to carry out learning with learning models determined in the 2013 Curriculum are in the good category; and (3) constraints that become obstacles for Public High School Physics teachers in applying learning models determined in the 2013 Curriculum, namely changes to the syllabus format, time allocation and stages in organizing in implementing the 2013 Curriculum learning model, and implementing attitude competency assessments.

However on the other hand based on the results of research by Kustijono (2014) there are still many teachers who do not understand the principles of assessment, preparation of lesson plans, learning activities, assessment activities, expectations and challenges of 2013 Curriculum implementation. National data obtained data that the indicators of physics teacher achievement are relatively low, both pedagogical and professional competence. For pedagogic competencies, there are 12 indicators, the number of teachers answering correctly in the range of $20 \%$ to $40 \%$, while professional competencies have 25 indicators. There are 6 indicators of pedagogic competence, where the number of teachers is correct at the middle level, which is between $40 \%$ and $60 \%$, while professional competencies are 28 indicators. Only 3 indicators of pedagogic competence have the highest number of teachers answering correctly at $60 \%$ to $80 \%$, while there are 5 indicators of professional competence. More than $60 \%$ of participants answered correctly of pedagogic competence (Bakri, Raharjo 2015).

According to the results of the physics teacher competency test analysis, obtained data that the teacher's ability to determine the maximum kinetic energy of electron photos at a specific frequency based on the graph of maximum kinetic energy frequency function is still relatively low at $31.7 \%$. This material is the subject of the photoelectric effect. Photoelectric effect material is very important material for students to achieve basic competencies, namely understanding the phenomena of the photoelectric effect and X-rays in everyday life. Also the basic competence is to present the results of data analysis about the application of photoelectric and X-ray effects in everyday life.

Various studies on the photoelectric effect have been carried out. Asyhari et al. (2016) developed a PhET-based conceptual instruction worksheet in developing teaching materials to construct students' 
concepts in the photoelectric effect. Perdana et al. (2017) developed student worksheets based on PhET-assisted interactive simulation discovery learning on newton. Supurwoko et al. (2017) a study on the effect of using PhET on understanding the concept of prospective teacher students. Research on the understanding of prospective teacher students about the photoelectric effect found a lack of understanding of students about the photoelectric effect (Siswoyo 2015). Concrete examples of activities of PhET Interactive Simulations have been used effectively (Perkins et al. 2012). Colorado University introduces some of the PhET sims and provides some suggestions for how to effectively use our sims in different learning environments (Perkins et al. 2006).

One of the learning strategies that can be applied is the strategy of Explain (POE). Ayvac1, HS (2013) examined the effectiveness of the POE strategy in learning photoelectric effects, as well as Karamustafaoğlu, S (2015), and Kibirige et al. (2014). The three researched the effect of the POE strategy on understanding the concepts learned. Multimedia supported POE tasks represent a new development in the use of the POE strategy in science education (Matthew at al. 2001), and computerbased POE tasks supported students' peer-learning conversations, particularly during the prediction, reasoning, and observation stages of the POE strategy (Branch 2009).

Based on the above, it is clear the importance of physics learning by using the Predict-ObserveExplain (POE) strategy that uses multimedia such as PhET interactive simulation. One of the most important topics to be mastered by students is the photoelectric effect. To be able to facilitate student learning, the teacher needs to obtain guidelines for implementing learning about the photoelectric effect as outlined in the form of a teacher manual on learning photoelectric effects with the Predict-ObserveExplain strategy based on PhET interactive simulation. So far, the research that has been carried out only develops student worksheets, while research on developing teacher guidelines in teaching specific topics, especially the photoelectric effect is still very lacking. It is necessary to research developing teacher guidelines for learning photoelectric effects with the Predict-Observe Explain strategy by using PhET interactive simulation.

\section{METHODS}

\section{Research Purposes}

This study's purpose was to develop a teacher guidebook for photoelectric effects instructional with the strategy of Predict-Observe-Explain using PhET interactive simulation for physics learning in High School.

\section{Research Methods}

The study is the Development Method (Development Research) using the ADDIE Branch Model, R. M. (2009). The analysis is consisting of validating the performance gap, determine instructional goals, confirm the intended audience, identify required resources, determine the potential delivery system. In order to identify that, we did surveys and study literature of the audiences to collect data about them. The first stage, namely the performance analysis is carried out to find out and clarify whether the performance problems encountered require a solution in the form of implementing a learning program or improving management. In the second stage, the needs analysis is a step needed to determine the abilities or competencies that need to be learned by students to improve learning performance or achievement.

Designs are consisting of conducting a task inventory and compose performance objectives. Documentation of project instructional, visual and technical design strategies apply instructional strategies according to desired behavioral outcomes based on domains (cognitive, affective, psychomotor). Create storyboards: design user interface and user experience. They are making prototypes. Apply visual design (graphic design).

Develop are consisting of generating content, select to develop supporting media, develop guidance for the student, develop guidance for the teacher, conduct formative revisions, and conduct a pilot test. In the developing phase, there are two main objectives that need to be achieved: First, producing, buying, or revising teaching materials that will be used to achieve the objectives of learning that were 
previously designed; Second, choose the best media that will be used to achieve learning objectives. Third, review and validate the result.

Implementation is consisting of preparing the teacher and prepare the student. The main objective of this implementation phase is to guide students to be able to achieve learning objectives, the occurrence of a problem solving or solution to overcome the gap in teacher learning outcomes, and finally ensure that at the end of the program teacher will have competence of knowledge, skills, and also a good attitude.

Evaluation is consisting of determining evaluation criteria, select evaluation tools, and conduct evaluation. Evaluation of the learning program has the aim to find out several things, including the attitude of teachers there are overall learning activities, increasing self-competence of teachers after getting a series of learning activities, and the benefits gained by the school after the learning program is applied (Wulandari 2016).

\section{Data collection technique}

There are four (4) validator in the development of a guidebook for teachers, namely:

1. Physicist namely a physics lecturer who has academic abilities in physics with a doctorate to validate the content.

2. Expert in science and learning media, namely a physics lecturer who has the ability and focus of expertise in the field of physics learning media to validate learning media

3. Physics education expert, namely a lecturer in physics education who has expertise and experience in physics learning both in college and in secondary school. The lecturer is a Professor in the field of physics education to validate learning concept

4. Physics teachers of high schools in Jakarta to asses the learning process.

\section{Data analysis technique}

The data collected are data from the validation results from experts and also the responses of high school teachers. Data were analyzed using a Likert scale. There are five assessment categories based on interpretation criteria, namely:

Score 5: Strongly agree

Score 4: Agree

Score 3: Hesitate

Score 2: Less agree

Score 1: Disagree

To determine the percentage of success, use the following calculation: $\mathrm{P}=\mathrm{S} / \mathrm{N}$ x100\%. Information:

$\mathrm{P}=$ presentation of success $(\%)$

$\mathrm{S}=$ amount of value acquisition

$\mathrm{N}=$ total maximum value

TABLE 1. Interpretation of scores is calculated based on the score of each aspect

\begin{tabular}{cc}
\hline Percentage & Interpretation \\
\hline $0 \%-20 \%$ & Very inappropriate \\
$21 \%-40 \%$ & Not feasible \\
$41 \%-60 \%$ & Fair enough \\
$61 \%-80 \%$ & feasible \\
$81 \%-100 \%$ & Very feasible \\
\hline
\end{tabular}




\section{RESULTS AND DISCUSSIONS}

\section{Description of Development Results}

\section{Book Cover}

The book cover displays images of solar cells and CCDs that symbolize the use of the working principle of the photoelectric effect on technology products. The background of the book is brighter blue.

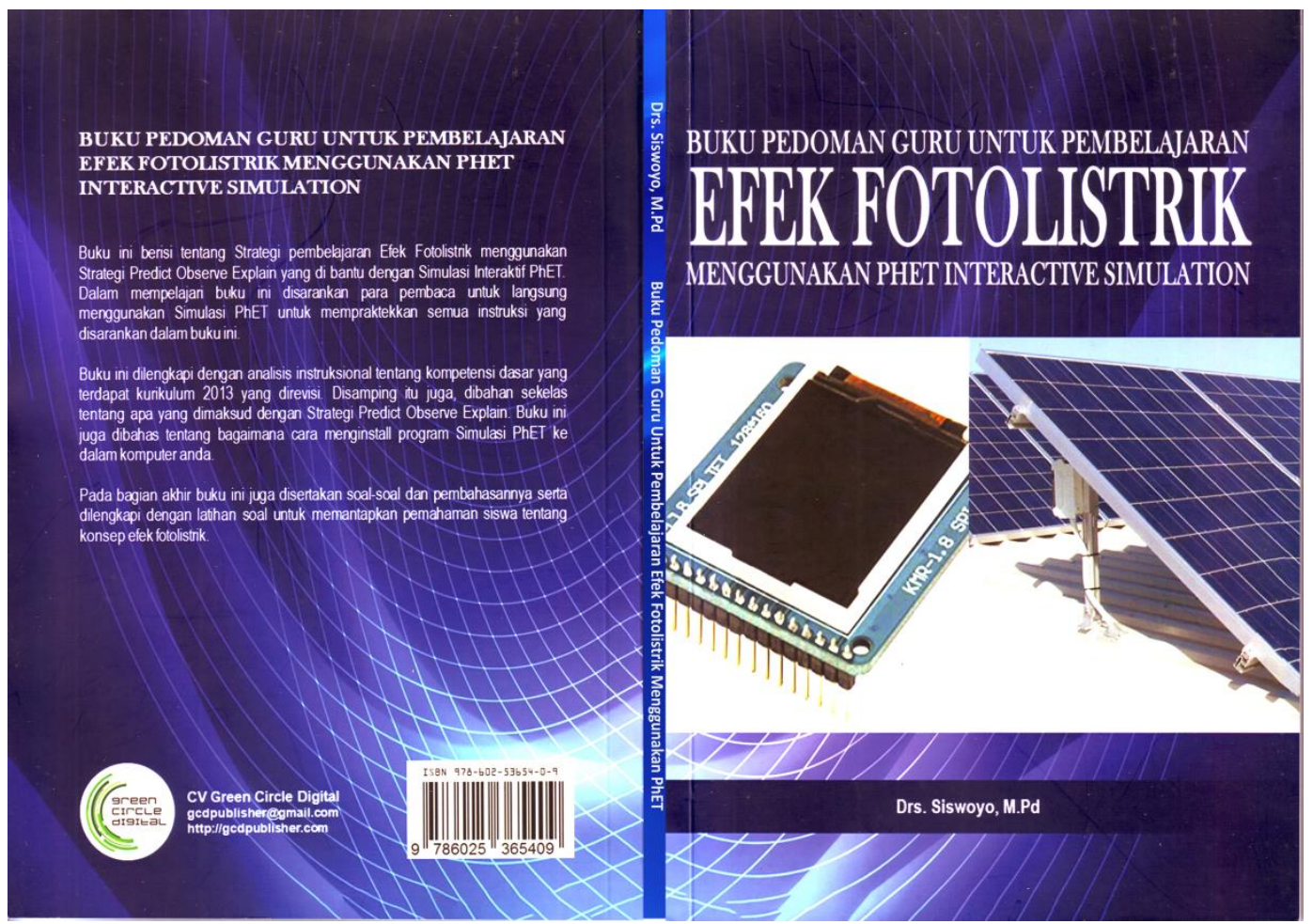

FIGURE 1. Book Cover

\section{Book Content}

Chapter I contains how to do instructional analysis. The instructional analysis is the process of describing basic competencies into indicators that are arranged logically and systematically. The activity is intended to identify a list of indicators and develop relationships between indicators towards basic competencies. The instructional analysis results are sub competency maps or indicator maps that show the most basic to the highest sub competency or indicator arrangement. The sub competency map or indicator map has a hierarchical, procedural, grouping, and combination structure.

Chapter II discusses the Predict Observe Explain Strategy. The discussion begins by defining the understanding of learning strategies. Then proceed with discussing the grouping of learning strategies into five big groups. The learning strategy chosen was to Predict Observe Explain (POE). The discussion focused on the steps of the POE learning strategy.

Chapter III presents an interactive simulation of PhET. It starts by explaining in general what is meant by an interactive PhET simulation, followed by discussing the characteristics of an interactive PhET simulation and some features possessed by an interactive PhET simulation. Lastly explained how to play interactive PhET simulations both online and off-line, including how to install PhET off-line.

Chapter IV presents the simulation of the PhET Photoelectric Effect. This chapter specifically discusses the photoelectric effect simulation using PhET. The discussion begins by explaining how to access interactive PhET photoelectric effects simulations and their features. Then discuss a number of activities that can be carried out using a PhET photoelectric effect simulation, including: 
1) Determine the relationship between current and intensity

2) The relationship between frequency or wavelength with current

3) Determine the size of the metalworking function

4) Determine the relationship between current and voltage

5) Shows potential stopping

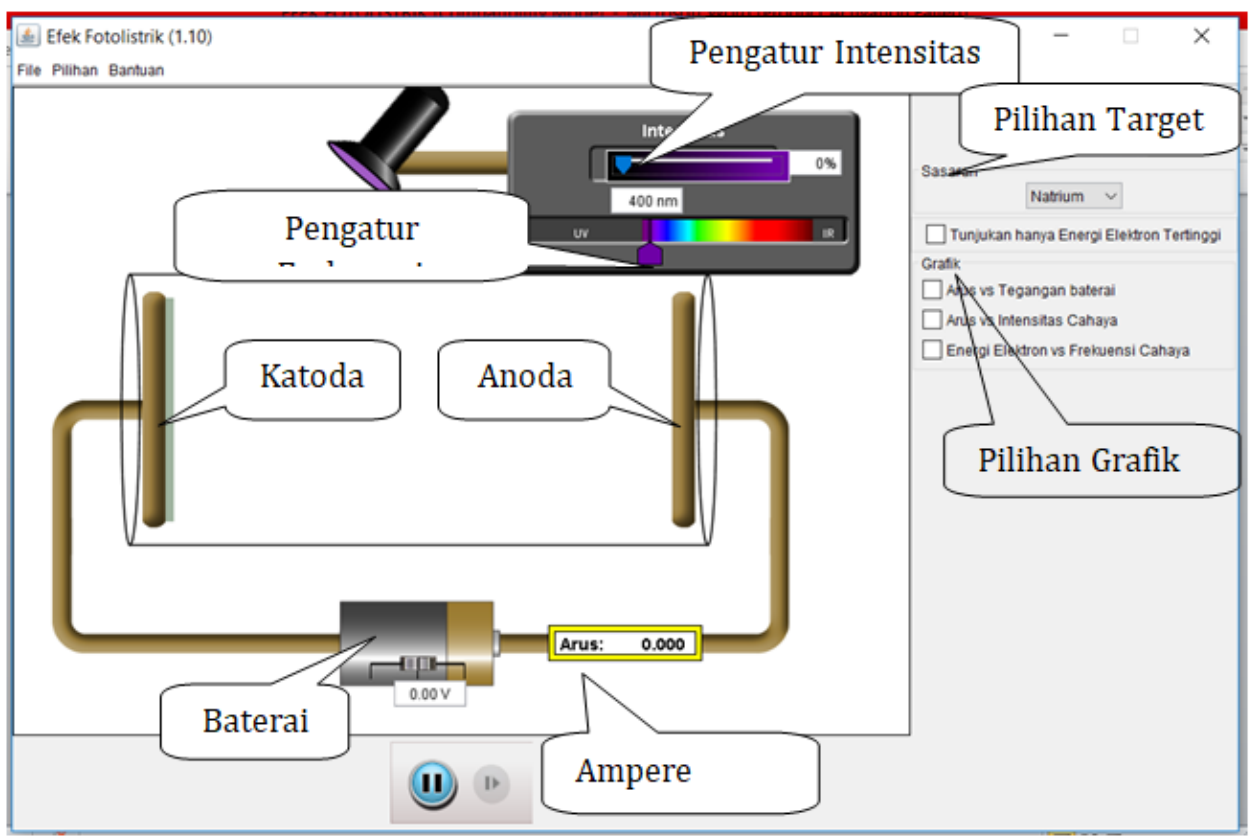

FIGURE 2. Photoelectric effect

Chapter V presents the application of the photoelectric effect in technology products. The technological products described in this chapter are solar cells, Charge Coupled Devices (CCD) and Complimentary Metal-Oxide Semiconductor (CMOS) and the working principle of photocopying machines.

Chapter VI presents the Problem and its discussion. After studying this chapter the reader is expected to be able to mention the factors that influence the amount of maximum kinetic energy on the photoelectric effect; mention the factors that cause photo-electrons to occur; mention actual facts about the photoelectric effect; interpret graphs of the relationship between kinetic energy and frequency in the photoelectric effect event; determine metal working functions based on graphs of the relationship between kinetic energy and frequency in the photoelectric effect event; interpret graphs of the relationship between electron kinetic energy and photon frequency; determine what factors must be changed so that the surface of the cathode emits photos of electrons; determine the maximum kinetic energy of photoelectrons; determine the amount of sodium stopping potential when exposed to light; interpret the graph of the relationship between current, voltage and intensity on potential stopping events.

Chapter VII presents the Question Exercise. After studying this chapter the reader is expected to be able to understand the properties of photons; identify the concept of photons in the photoelectric effect event; indicates that the photoelectric effect will occur if the frequency (wavelength) and light intensity are sufficient (appropriate); explain the relationship between current and intensity; graph the relationship between current and intensity; explain the relationship between frequency and current; interpret graphs of the relationship of electron kinetic energy with frequency; determine the function of several metalworking; show the relationship between current and voltage; graph the relationship between current and voltage; explain the relationship between current and voltage; shows the stopping potential of each target metal (target); calculate the stopping potential of different target metals; define the meaning of potential stopping; graph the relationship between potential stopping, current and intensity; understand the phenomenon of the photoelectric effect on solar cells; understand the 
phenomenon of the photoelectric effect on CCD or CMOS; understand the phenomenon of the electric photo effect on copy machines.

\section{Description of Validation and Readability Test Results}

Validation of the results of the development was carried out by three experts, namely graphics expert, contents expert, and learning expert. Each expert conducts validation using different validation instruments. After the validation was revised, then the readability test was conducted by the teacher by assessing based on their expertise in learning physics in high school.

\section{Validation of Graphics}

Validation of graphics consisting of 4 criteria 1) book size, 2) book cover, 3) book layout, and 4) book typography. Scoring scale use Likert 1-5 scale is consisting 0-100\%.

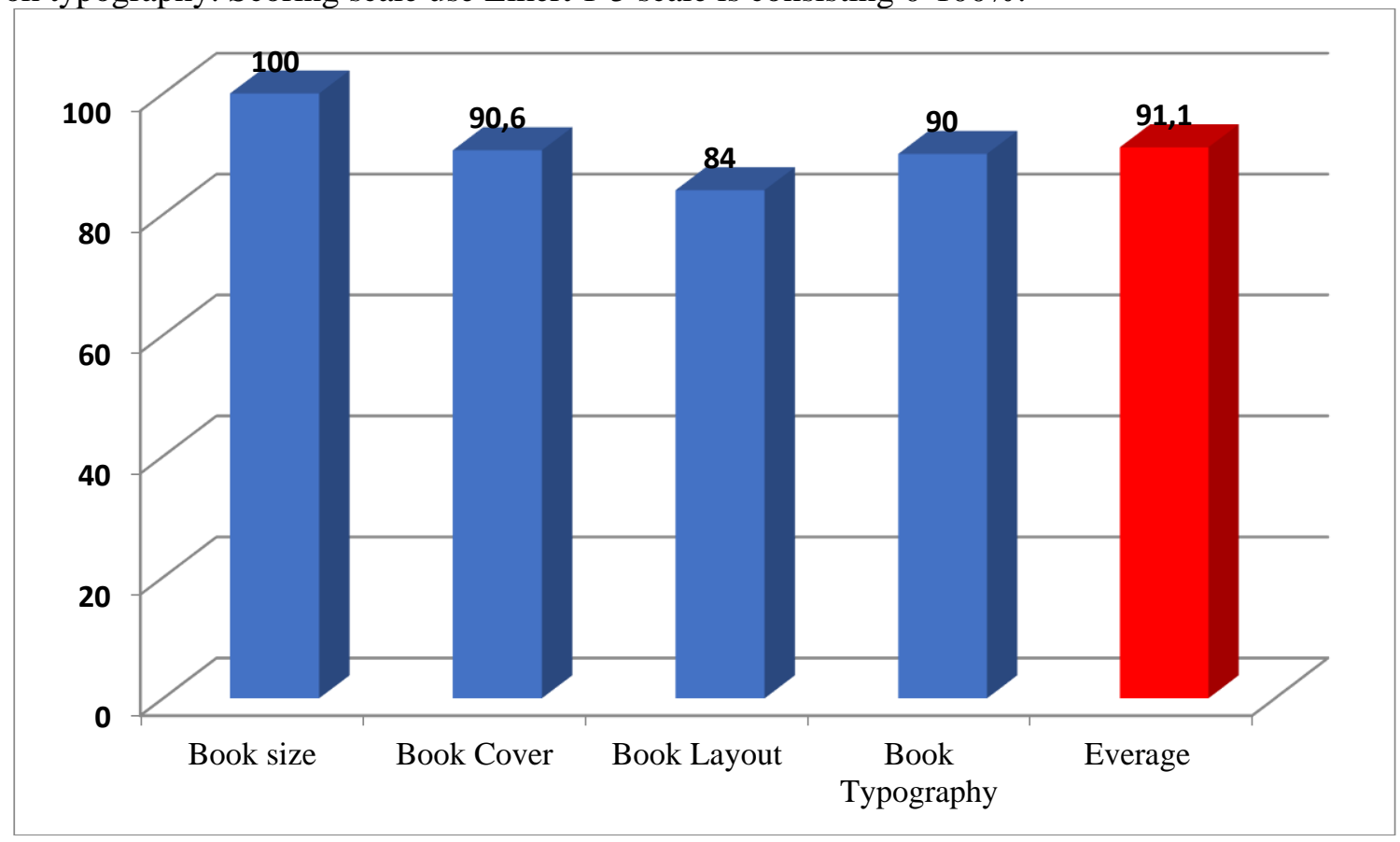

FIGURE 3. The result of Validation of Graphics

\section{Validation of Content}

Content feasibility validation was assessed based on three criteria, namely: 1) Dimension of knowledge (cognitive), 2) Dimensions of update and contextual, 3) Dimension of Skills.

The Knowledge Dimension (cognitive) consists of a) the scope of the material in accordance with the basic competencies contained in the curriculum, b) the completeness of the material in accordance with indicators of competency achievement, c) the breadth of material in accordance with basic competencies, d) the depth of material in accordance with indicators of achievement of competencies, e) Accurate facts, f) concepts/principles/laws/theories that are presented accurately or not wrongly concepts, g) procedures used in accordance with scientific rules, h) illustrations/images support an understanding of the concept of the photoelectric effect.

The Dimension of Entrepreneurship and Contextual consists of a) material in accordance with the development of physics, b) the material follows the latest developments, c) the material related to the application of concepts in everyday life, d) material explores the potential that exists in Indonesia material using Information and Communication Technology (ICT).

Skill dimensions consist of: a) material presenting science process skills, b) material supports the formation of scientific attitudes, c) material supports the formation of teacher insights about science learning strategies, d) procedures for activities carried out accurately; e) steps of activities forming 
skills in exploring the concept of photoelectric effects, f) teacher skills in conducting instructional analysis.

The rating scale used in the validation instrument is the Likert scales 1-5, with a range of strongly disagreeing until strongly agree. The instrument uses a score interpretation on the Likert scale, namely $0 \%-100 \%$, with a range from very inappropriate to very feasible. The following are data obtained from the results of the validation of material eligibility:

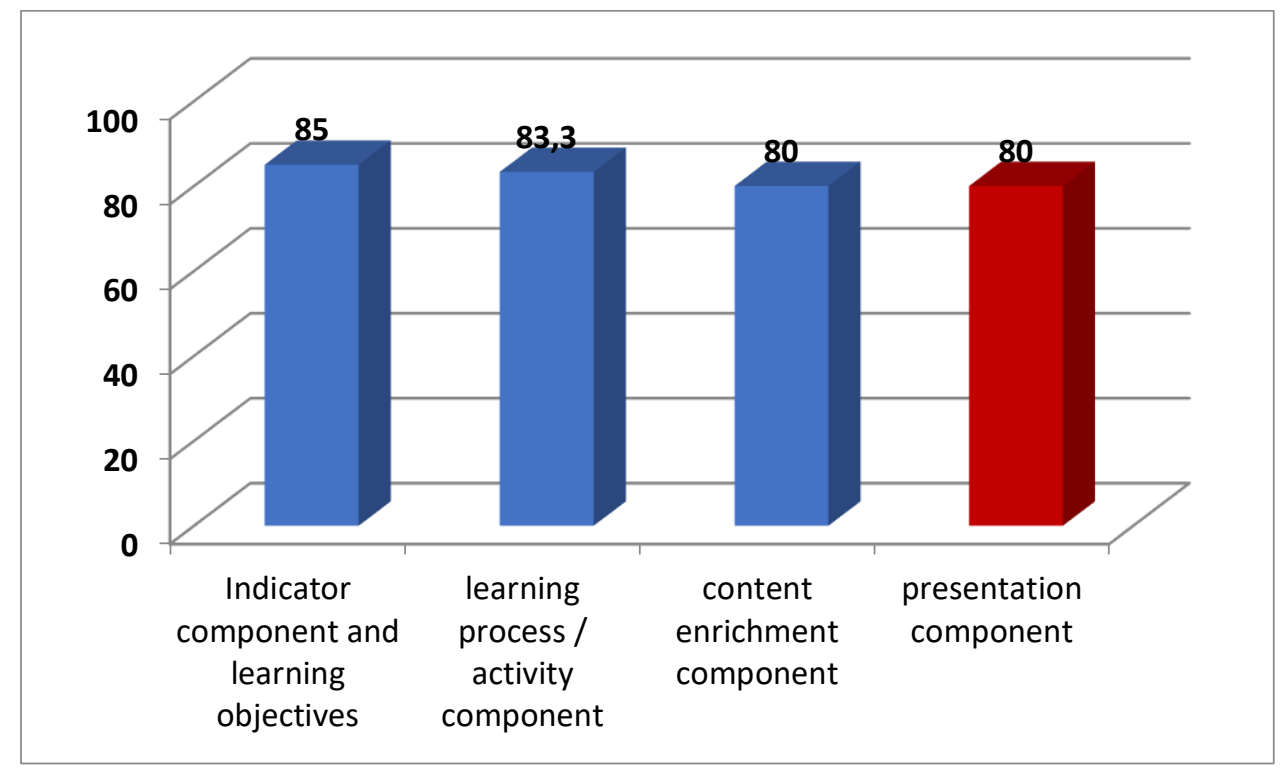

FIGURE 4. The Result of Validation of Content

\section{Validation of instructional}

Instructional feasibility validation is assessed based on specific criteria, namely 1) indicator component and learning objectives, 2) learning process/activity component, 3) content enrichment component, 4) presentation component, 5) linguistic component.

Components of indicators and learning objectives consist of: a) there are basic competencies to be achieved, b) indicators of achievement of competencies following basic competencies, c) learning objectives following indicators of achievement of competencies, d) activities or experiments arranged following learning objectives.

The components of the learning process/activities consist of: a) the stage of the activity of predictobserve-explain is done clearly, b) learning activities are clear (not confusing), c) activities related to knowledge: remembering, understanding, applying, analyzing, evaluating, and creating, d ) activities related to skills: observing, asking, trying, reasoning, and presenting (5M), e) Activities providing alternatives to $5 \mathrm{M}$ (observing, asking, trying, reasoning and presenting), f) activities using appropriate learning media ( simulation media).

Content enrichment components consist of: a) facts presented accurately, b) concepts/principles/laws/theories which are presented accurately or not wrongly concepts, c) procedures used in accordance with scientific rules, d) material in accordance with the development of physics, e) material follows the latest (latest) developments, f) material related to the application of concepts in everyday life, g) material using Information and Communication Technology (ICT).

The presentation component consists of a) there are advance organizers or instructions for using the book, b) the presentation is done in stages and systematically, c) illustrations/images are presented clearly, d) tables are presented clearly, e) exercise questions and discussion is sufficient.

Language components consist of: a) the exact structure, b) the terms used in the standard, c) the meanings listed in the chapter / sub-chapter / paragraph appear intact, d) there is a connection between the chapter / sub-chapter / paragraph, e) the language used is right, f) the spelling used is right, g) the term used is consistent, h) the symbol/symbol used is consistent, i) the writing of the scientific/foreign name is appropriate, $\mathrm{j}$ ) the bibliography used is appropriate and supports the contents of the book. 
The rating scale used in the validation instrument is the Likert scales 1-5, with a range of strongly disagreeing until strongly agree. The instrument uses a score interpretation on the Likert scale, namely $0 \%-100 \%$, with a range from very inappropriate to very feasible. The following are data obtained from the results of the validation of learning feasibility:

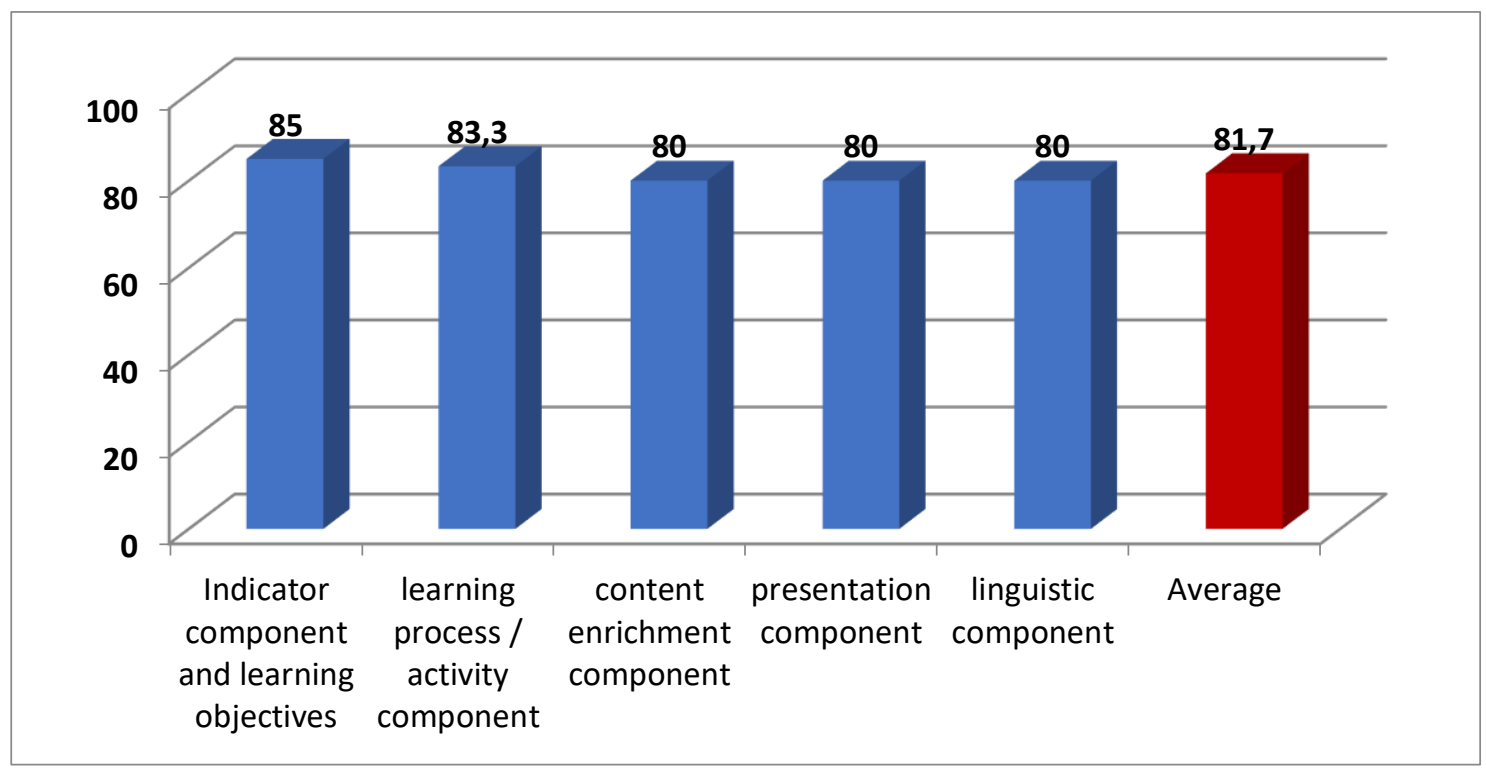

FIGURE 5. The Result od Validation of Instructional

\section{Teacher Readability Test Results}

Readability test is assessed based on five criteria, namely 1) indicator component and learning objectives, 2) learning process/activity component, 3) material enrichment component, 4) presentation component, 5) linguistic component. Readability tests were carried out by three teachers in a high school in Jakarta.

Components of indicators and learning objectives consist of: a) there are basic competencies to be achieved, b) indicators of achievement of competencies following basic competencies, c) learning objectives following indicators of achievement of competencies, d) activities or experiments arranged following learning objectives

The components of the learning process/activities consist of: a) the stage of the activity of predict observe explain is done clearly, b) learning activities are clear (not confusing), c) activities related to knowledge: remembering, understanding, applying, analyzing, evaluating and creating, d ) activities related to skills: observing, asking, trying, reasoning, and presenting (5M), e) Activities providing alternatives to $5 \mathrm{M}$ (observing, asking, trying, reasoning and presenting), f) activities using appropriate learning media ( simulation media).

Material enrichment components consist of: a) facts presented accurately, b) concepts/principles/laws/theories which are presented accurately or not wrongly concepts, c) procedures used in accordance with scientific rules, d) material in accordance with the development of physics, e) material follows the latest (latest) developments, f) material related to the application of concepts in everyday life, g) material using Information and Communication Technology (ICT).

The presentation component consists of a) there are advance organizers or instructions for using the book, b) the presentation is done in stages and systematically, c) illustrations/images are presented clearly, d) tables are presented clearly, e) exercise questions and discussion is sufficient.

Language components consist of: a) the exact structure, b) the terms used in the standard, c) the meanings listed in the chapter / sub-chapter / paragraph appear intact, d) there is a connection between the chapter / sub-chapter / paragraph, e) the language used is right, f) the spelling used is right, $\mathrm{g}$ ) the term used is consistent, $\mathrm{h}$ ) the symbol/symbol used is consistent, $\mathrm{i}$ ) the writing of the scientific/foreign name is appropriate, $\mathrm{j}$ ) the bibliography used is appropriate and supports the contents of the book. 
The rating scale used in the validation instrument is the Likert scales 1-5, with a range of strongly disagreeing until strongly agree. The instrument uses a score interpretation on the Likert scale, namely $0 \%-100 \%$, with a range from very inappropriate to very feasible. The following are data obtained from the results of the validation of learning feasibility:

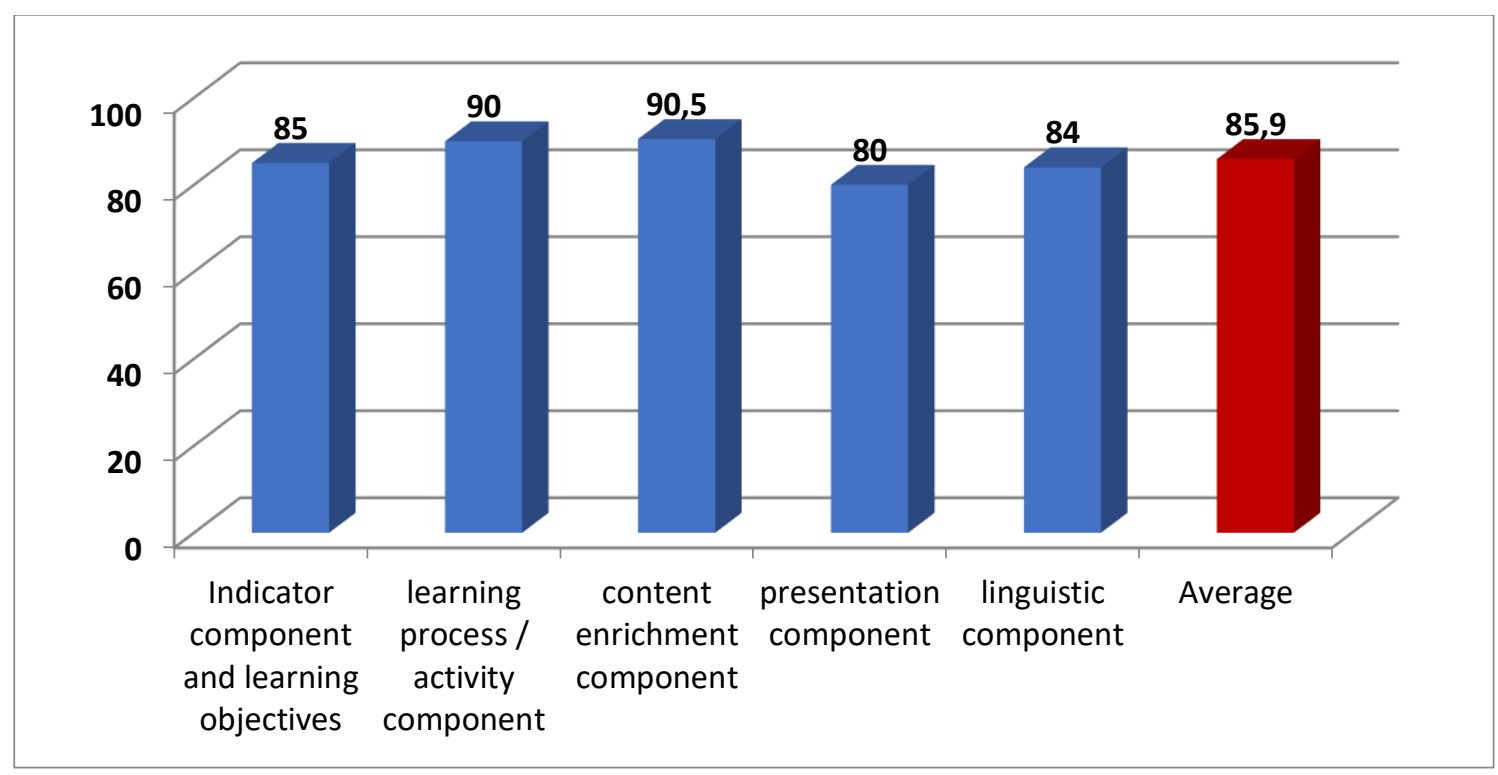

FIGURE 6. Teacher Readability Test Results

Based on the results of the research above, further experimental research can be done to determine the effect of the teacher guide book on student learning outcomes.

\section{CONCLUSIONS}

The teacher's guidebook for photoelectric effect instruction is concluded to be very feasible to be stated as the teacher's guidebook in teaching the photoelectric effect in class XII of High School.

\section{REFERENCES}

Admoko, S, Supriyono 2016, 'Workshop Peningkatan Merancang Kegiatan Laboratorium Berorientasi Pada Pendekatan Saintifik Bagi Guru Fisika Sidoarjo', Jurnal Penelitian Fisika dan Aplikasinya, vol. 6, no. 1, pp. 34-42.

Asyhari, Ardian, Irwandani, \& Herli Candra Saputra, HC 2016, 'Lembar Kerja Instruksi Konseptual Berbasis Phet: Mengembangkan Bahan Ajar Untuk Mengkonstruksi Konsep Siswa Pada Efek Fotolistrik', Jurnal Ilmiah Pendidikan Fisika 'Al-BiRuNi', vol. 5, no. 2, pp.193-204.

Ayvac1, HS 2013, 'Investigating The Effectiveness of Predict-Observe-Explain Strategy On Teaching Photo Electricity Topic', Journal of Baltic Science Education, vol. 12, no. 5, pp. 548-564.

Bakri, F, Raharjo, SB 2015, 'Analisis Hasil Uji Kompetensi Guru Fisika', Jurnal Penelitian \& Pengembangan Pendidikan Fisika (JPPPF), vol. 1, no. 1, pp. 91-96.

Branch, RM 2009, Instructional Design: The ADDIE Approach, Springer, New York.

Fadilah, NU, Suparwoto 2016, 'Keterlaksanaan Pembelajaran Fisika Implementasi Kurikulum 2013 Berdasarkan Latar Belakang Akademik Guru', Jurnal Inovasi Pendidikan IPA, vol. 2, no. 1, pp. 7687.

Istiyono, E, Suyoso, \& Kadarisman, N 2017, 'Pelatihan Penyusunan Instrumen Penilaian Ranah Psikomotor (Keterampilan) Bagi Guru-Guru Fisika SMA/MA di Yogyakarta', Jurnal Pengabdian Masyarakat MIPA dan Pendidikan MIPA, vol. 1, no. 2, pp. 81-84. 
Kaleka, MU 2014, 'Evaluasi Kemampuan Guru Fisika SMA dalam Menyusun Instrumen Penilaian Hasil Belajar', Jurnal Pendidikan Fisika dan Aplikasinya (JPFA), vol. 4, no. 1, pp. 1-14.

Karamustafaoğlu, S 2015, 'Understanding Electrochemistry Concepts using the Predict-ObserveExplain Strategy', Eurasia Journal of Mathematics, Science \& Technology Education, vol. 11, no. 5, pp. 923-936.

Katherine, P, Adams, W, Dubson, D, Finkelstein, N, Reid, S, \& Wieman, C 2006, 'PhET: Interactive Simulations for Teaching and Learning Physics', The Physics Teacher, vol. 44, pp. 18-23.

Katherine, P, Moore, E, Podolefsky, N, Lancaster, K, \& Denison, C 2012, 'Towards Research-Based Strategies for Using Phet Simulations in Middle School Physical Science Classes', AIP Conference Proceding, vol. 1413, pp. 295-298 .

Kibirige, I, Osodo, J, \& Tlala, KM 2014, 'The Effect of Predict-Observe-Explain Strategy on Learners' Misconceptions about Dissolved Salts', Mediterranean Journal of Social Sciences, vol. 5, no. 4, pp. 300-310.

Kustijono, R, Wiwin, EHM 2014, 'Pandangan guru terhadap pelaksanaan kurikulum 2013 dalam pembelajaran fisika SMK di Kota Surabaya', Jurnal Pendidikan Fisika dan Aplikasinya (JPFA), vol. 4, no. 1, pp. 1-14.

Matthew, K, Treagust, DF, Yeo, S, \& Zadnik, MG 2001, 'Student and Teacher Perceptions of the Use of Multimedia Supported Predict-Observe-Explain Tasks to Probe Understanding', Research in Science Education, vol. 31, pp. 589-615.

Perdana, A, Siswoyo, \& Sunaryo 2017, 'Pengembangan Lembar Kerja Siswa Berbasis Discovery Learning Berbantuan PhET Interactive Simulations Pada Materi Hukum Newton', Jurnal Wahana Pendidikan Fisika, vol. 2, no. 1, pp. 73-79.

Putri, RF, Jumadi 2017, 'Kemampuan Guru Fisika dalam Menerapkan Model-Model Pembelajaran pada Kurikulum 2013 serta Kendala-Kendala yang Dihadapi', Jurnal Inovasi Pendidikan IPA, vol. 3, no. 2, pp. 201-211.

Siswoyo 2015, 'Pemahaman Mahasiswa Tentang Efek Fotolistrik', Jurnal Penelitian \& Pengembangan Pendidikan Fisika (JPPPF), vol. 1, no. 1, pp. 77-84, doi: doi.org/10.21009/1.01111

Supurwoko, Carib, Sarwanto, Sukarmin, \& Suparmi 2017, 'The effect of Phet Simulation media for physics teacher candidate understanding on photoelectric effect concept', International Journal of Science and Applied Science: Conference Series, vol. 1, no. 1, pp. 33-39.

Wulandari, RW, Mundilarto 2016, 'Kompetensi Pedagogik dan Profesional Guru Fisika dalam Melaksanakan Pendekatan Saintifik', JPFK, vol. 2, no. 2, pp. 92-104. 
